\title{
Heard But Marginalized: A Case Study of Chinese NGOs in the Anti-domestic Violence Legislation
}

\begin{abstract}
Yi Shi
Rutgers University Newark Institute, Northeast Normal University, China

shiy409@nenu.edu.cn

ABSTRACT

This paper examines the interactions of Chinese NGOs and the government, before and after the legislation of antidomestic law. In 1995, the Fourth World Congress of Women held in Beijing remarks on Chinese determination to engage in public affairs globally; afterward, concepts of anti-domestic violence and NGOs have come into China With further connection with the world, China has accepted the normative practice that NGOs are vital for solving domestic violence. It has resulted in the isomorphic strategies adapted by early anti-domestic violence NGOs in China, learning from the successful foreign models. However, the Chinese government also feels alert to NGOs' assumption from the western experience of expanding civil society instead of the official. With the development of the antidomestic violence movement, NGOs, in turn, display a unitive tendency to get closer to the authorities. This article argues that the government achieves the localization of NGOs in the Chinese context during the past two decades of the ant-domestic violence movement. The enactment of the law in 2016 promotes solving domestic violence and reaffirming the official authority in public affairs.
\end{abstract}

Keywords: NGOs, anti-domestic violence, institutional isomorphism, authoritarianism.

\section{INTRODUCTION}

Since the 1980s, NGOs are surging around the world, especially in developing countries. Brazil had an estimated 110,000 NGOs by 1993 , thus becoming the largest NGO sector in the developing world, and India, as the second-largest, had more than 100,000. Large numbers of NGOs in developing countries, financially sponsored by organizations in developed countries, tend to take on the responsibility of alleviating material inequalities and are prospective in promoting domestic democratization. Although the concept of fulfilling the blank between the state and citizens traces from the Western, the collective action of civil society and nonprofit organizations in social welfare are advocated both in developed countries and some developing countries as a common practice.

PRC is not an exception. Since the opening-up policies in the late 1970s, China has witnessed the boom of NGOs. Chinese NGOs participate in civil society ranging from education, health, and environment, and meanwhile, concern for various inequalities by offering welfare and services. Organizations in China are divided into three categories: Party's state organs, people's organizations, and NGOs. People's organizations are those associations organized by the broad concept of "people," and meanwhile, being accepted and approved by the state. However, due to the regulative system, it is unlikely to find a complete "non-governmental" NGO in China, thus making the boundary between people's organizations and NGOs ambiguous. The government also tends to manage them together for convenience. For example, the All-China Women's Federation (ACWF) is a recognized people's organization by officially established, and whereas it is different from the official departments. ACWF, along with other NGOs, has successfully promoted the legislation of the antidomestic violence law during the past twenty years. By examining the development of the anti-domestic violence course in China, the evidence of NGOs vis-àvis states can be found.

This article begins with a literature review of government-NGO relations in developing countries and institutional isomorphism theory, a rising perspective in understanding the complex relations of NGOs and the government. Then what followed is the study's findings: 
a summary of how domestic violence movement is legalized in China with a dynamic interaction between the government and NGOs from 1996 to 2020. The final section explains that under an authoritarian state, how organizations become isomorphic, and how the government achieves the incorporation of NGOs with solving social issues.

\section{LITERATURE REVIEW}

\subsection{Institutional Isomorphism Theory}

Before learning about the literature about government-NGO relations, it is necessary to introduce the theory used in this paper. Institutional isomorphism theory, developed by DiMaggio and Powell (1983), explains the trend that once an organizational field is established, organizational forms and practices within will become homogenous. In contrast to past organizational theories that focus on explaining the variation in organizations (Woodward, 1965), Institutional isomorphism theory shifts the focus on why organizations are so similar (Frumkin \& Galaskiewicz, 2004). Stem from the observations by Meyer and Rowan (1977) that nonprofit organizations legitimize themselves by enhancing the level of organization with regulatory pressure, DiMaggio and Powell (1998) propose that this similarity associate with imitation among different institutions or through the evolution of systems independently. The three mechanisms of isomorphic institutional change are coercive, mimetic, and normative. Coercive isomorphism comes from the pressures imposed on organizations by other organizations that they rely on or "by cultural expectations in the society within which organizations function" (DiMaggio \& Powell 1983, 150). When organizations confront outside supervision, they are guided to find the appropriate approaches in an isomorphic way to eliminate stress. The second type of isomorphism is mimetic, resulting from uncertainty. In an uncertain environment, organizations will copy the successful "modeled organizations" to avoid the potential risks and maximize profits (Alchian, 1950, 212). The third is normative isomorphic, and this is derived from the increasing demands of professionalization. Within the same industry, it can be found that from enrollment to promotion, the organizations' internal career development and preferences for professional employees are similar, thus encouraging homogenization over the long run.

Massive literature rising from the 2000s attempt to explain the complex relations of NGOs and the government in different contexts from the view of institutional isomorphism. For instance, Ramanath (2007) argues that in Mumbai, India, NGOs are "using aggressive strategies manage a shift to more cooperative interactions with the state (52). Responding to the housing policy changes of the 1990s, three NGOs participate in the transformation isomorphically "both in means and processes.". This example implies that isomorphic change processes can be "observed not merely through examination of structural features of organizations but also manifest themselves in internal decision-making processes and behavioral features" (Ramanath, 2007, 54). Besides the demonstration of NGOs in developing countries, the related literature can also be found in the analysis of developed countries. Mature community mediation centers tend to be "isomorphic with more established governmental social control agencies to manage resource uncertainties" (Morrill \& Mickee, 2014, 445). It remains problematic that survival strategies result in the community mediation programs becoming "isomorphic members in organizational fields of social control agencies" (Morrill \& Mickee, 2014, 458). Thereby, Institutional isomorphism theory is utilized here to provide a significant angle to reflect the puzzle that NGOs lose the innovative capacity in some contexts, duplicating the rigid hierarchy similar to governmental characteristics.

Moreover, Dogra (2012) analyzes similar images in international NGOs, as Anheier (2005) conveys that many common characteristics are found in INGOs. A remarkable instance is that to accelerate the delivery of INGOs' messages, INGOs prefer simplification and are likely to abandon the in-depth expressions. Overall, Institutional Isomorphism Theory, as a novel tool to inspect the NGOs vis-à-vis states under various circumstances, has been practiced in abundant anglophone literature.

\subsection{Origins of inevitable tense?}

During the past decades, the relationship between NGOs and the government and promoting civil society has become a focus of NGO study. Within the literature, some controversial aspects also can be captured. The first controversy is the adversarial relationship between NGOs and the government. Since NGOs are independent of the government, they are usually supported by the civil society or, in many cases, rely on international funds. The separation capital source of NGOs from the government makes them possess the autonomy of political action. On the one hand, the source of tension is the assumption that NGOs can challenge the official regime, especially in several countries that have gone through regime consolidation yet. Clarke (1998) argues that in the period from the mid-1990s, NGOs became a noticeable political power in the Philippines, Thailand, Vietnam, and other Southeast Asia countries. In Vietnam, "indigenous" NGOs, legitimated in 1991, are obliged by Law. Whereas NGOs are "increasing their autonomy from state-controlled mass organizations" (36). In Chile, NGOs helped to restructure the left-wing opposition 
during the mid-1970s (Schild, 2002). NGOs can influence or pose a significant impact on public policy and aggressively respond to the hegemony.

On the other hand, the ideological premise of NGOs results in the mutual distrust of NGOs and governments. The arose of NGOs follows a neoliberal turn in the West, where the "new public management" (Hood, 1991) becomes a prevailed trend. The traditional hierarchical management model is challenged. Instead of relying on a strong government to provide comprehensive public services, governments prefer outsourcing to private organizations, known as "thirdparty government." Derived from the Western experience and contexts, therefore when introduced worldwide, NGOs result in disagreements with authoritarian states like in several post-soviet countries. Critique of the anti-domestic violence campaign in Armenia reflects the contradictions because of the influence from Western donors (Ishkanian, 2007). In Armenia, most women's rights NGOs did not start carrying out protecting projects until the Western claim of large grant programs. The Women's rights issue is likely to be viewed as a field of ideological confrontation rather than a severe social issue to be solved.

\subsection{The agent of grassroots: promote good governance or threaten the legitimacy?}

Another aspect that NGO literature concerns is the possibility that NGOs fill civil society's gap in public service delivery. Brass (2012) argues that in Kenya, "need factors" are the primary motivation for NGO placement (6). Furthermore, empirical evidence has implied that in rural areas, there locates more NGOs to provide services. NGOs select the poorest region to provide aid after complete assessing distributions of extreme demands. In Bangladesh, India, Nepal, Indonesia, Thailand, and the Philippines, NGOs are remarkable in promoting agricultural technology development (ATD) to enhance livelihoods among the rural poor, reflecting NGOs' particular strengths in promoting sustainable development. (Farrington \& Lewis, 2014). The debate here is the extent to which NGOs can represent the poor's interests, empower those under threat, and then push the building of a civil society in other developing countries.

In some cases, it is inappropriate to regard NGOs' importance of fostering a civic society power as a panacea, thereby underrating the complexity of various political contexts. In Uganda, NGOs' empowering and democratizing potential relies on restrictions "by stateimposed bottlenecks, structural and historical impediments, and internal NGO limitations" (Dick \& Litch, 1998, 10). One issue is that many African NGOs tend to be organizationally weak and seldom truly rooted from the people (Fowler, 1993). Furthermore, the political elites often utilize them to enrich themselves by providing diverse patronage resources (Coninck, 1992).

This phenomenon is the same in Ethiopia (Campbell, 2001). Clark (2000) suggests that the government restricts NGOs' activities. Moreover, NGOs' efficiency is overrated in Ethiopia. Local NGOs tend to be "slow and difficult because of limited capacity in strategic conceptualization, service delivery, and financial accountability (6)", being subjected to the division of many political or ethnic issues instead of seeking consensus.

The theme of whether NGOs can facilitate good governance is emerging in NGO literature. Many scholars argue that NGOs are making decisions together with the government rather than only performing policies (Peters \& Pierre, 1998, 224). Whereas, in some weak-institutionalized states, the introduction of NGOs is more likely to be a forced transformation. Some have observed a contradiction, like in Latin America. Gideon (1998) takes the UNICEF project in Guatemala City as a failed example to demonstrate that women "remain marginalized" rather than be liberated under the influence of liberalism. Although it is unreasonable to attribute the inherent gender issue to the liberal reform, Gideon (1998) points out that in Latin America, NGOs act as "contractors to implement programs without necessarily reflecting poor people's priorities" (309) and become the extension of the authority.

Furthermore, NGOs' systems in authoritarian states resemble strict hierarchical government structures. In Bangladesh, wood (1997) expresses that charismatic leadership makes strategies in NGOs from the topdown. The state and the sponsors control NGOs "are often internally undemocratic, characterized by authoritarian" (Mercer, 2002, 13). They violate the prospect that NGOs will break down the traditional structures in the society and promote good governance (Hadenius \& Uggla, 1996). What implies here is that NGOs may strengthen the state power of the democratic state and authoritarian ones. Because of NGOs' connection with democratic discourse, it can be observed that in some states, NGOs are incorporated into the official narrative to sustain the status quo. In Brazil, NGOs are subsidized by the government. As a result, the "government-citizen policy councils" support the government subvention for NGOs; however, it is observed that in most cases, their role is more to endorse the government decisions rather than challenge them (Mercer, 2002, 17). Enlightened of the NGOs in Africa, a contradiction different from discussed above is that some scholars argue that flourish NGOs may threaten the state legitimacy. According to Fowler (1991), most African governments choose the governance system with fundamental weakness in failing to fulfill the social contract. Hence, the government is "incapable of providing for the sustainable well-being of citizens and 
failing to ensure public accountability" (78). In the postcolonial period, African governments' legitimacy comes from their economic progress and service provision commitments. Therefore, they are reluctant to "allow credit for socio-economic progress to accrue to any organization other than the state itself" (Bratton, 1989, 572). Batley and McLoughlin (2010) explain that when NGOs can provide essential services for the governed in fragile states, they may delegitimize the state.

In summary, literature discussing the relations of NGOs and governance is increasing. Meanwhile, more scholars avoid the complexity of this topic and advocate a normative assumption that NGOs are supposed to engage in the governance towards democracy. However, several examples in literature have demonstrated that NGOs are not necessarily as influential as assumed concerning cross the ethnic and regional barrier, seeking to break down the structural inequality and acting as a critical component in enhancing the civil society. Which type of NGO engagement in civic society is more veritable yet easier to achieve the public purpose? Do NGOs always act positively to frame their public career and adopt flexible strategies against pressure from the states? This paper will respond to the debates captured in the literature to fill the research gap by opening the discussion about the interaction of anti-domestic violence organizations and the Chinese government through the lens of institutional isomorphism theory.

\section{METHODOLOGY}

\subsection{Case selection}

This study chooses Beijing's local and central government and the anti-domestic violence NGOs. People in developed areas are likely to pay more attention to domestic violence, and Beijing is a typical example with the highest degree of modernity in China. In these areas, anti-domestic violence NGOs are becoming a rising civil society power, which has developed the anti-domestic violence movement in China during the past decades. Besides, Beijing is the Chinese capital and the political center, while antidomestic violence organizations in Beijing are dense and active. Therefore, the intensive network of NGOs and the centralized authority results in the complex relations between NGOs and the government.

\subsection{Documentary analysis}

This paper aims at responding to the puzzles by applying qualitative methods. Documentary analysis is the primary approach used in this study. The most crucial step is to review documents from three sources: the official, NGOs, and the third-party media. Official documents, like gazette, legislation, court rulings, and annual white book are included. The central state information source is from The People's Government of Beijing Municipality website and Public Security Bureau. By comparing the news about anti-domestic violence organizations appeared on their websites, it is possible to reflect changes in official attitude. One difficulty is that the records collected are usually not consistent enough and not updated regularly. Consequently, a particular year may be blank. However, the above missing data can be checked in NGOs' documents.

Secondly, reports of anti-domestic violence NGOs are reviewed. For example, the Women's Federation is considered to be the most influential NGO in China. Other major anti-domestic violence NGOs such as the Network for Combating Domestic Violence in China and Beijing Equality are also covered by viewing their plans, occurrence reports, project reflections, and yearly white books. From the documents of NGOs, their interactions with the official government in different periods can be captured. Thirdly, collecting the relevant news published domestically and internationally on third-party media like Southern Weekly and the BBC can reflect public opinion conversion.

\section{FINDINGS}

\subsection{Before 2016: NGOs take the initiative}

The attendance of The All-China Women's Federation (ACWF) in the Asia-pacific Women and Development NGO Conference (Manila, 1993) reiterated its intention to identify as an NGO and consequently tackle domestic violence and promote women's rights domestically. Although facing the query, ACWF is recognized by the government as the largest NGO protecting women's rights in China. In the 1990s and 2000s, ACWF was learning from other influential NGOs, improving its independence. On the official website of Beijing Women's Federation (BFW), the earliest formal records date back to 2011 that BWF advocates opinions of Beijing on preventing and stopping domestic violence with several official departments. In 2013, ACWF proposed that the antidomestic violence law is included in the NPC's legislative agenda. Since 2014, initiatives on actions against domestic violence have been increasing. During the National People's Congress (NPC), representatives of ACWF have always been putting forward suggestions on proposing an anti-domestic violence law in the legislative plan.

Another prominent NGO is Network for Combating Domestic Violence in China (DVN). In 1999, Professor Chen Mingxia of the Academy of Social Sciences founded it with Beijing professionals and scholars. DVN connected the existing non-governmental women organizations via the Internet, building an informationsharing platform for the cooperation of various gender equality organizations. The primary financial source 
was in the name of experts or organizational members to apply for foreign funding, including Ford Foundation and Swedish International Development Cooperation Agency. After 2000, DVN was affiliated with the China Law Society (CLS), and in this period, a common practice was that organizations affiliate themselves under the name of an official organization. In this way, NGOs tried to legitimize themselves politically. However, DVN was committed to promoting organizational specialization following the examples of international NGOs. Its recruitment and capital operation were independent, and every year accepted audit inspection from the investors. (Dong, 2015). Overall, DVN represented the rising civil society and helped to fill a longstanding official void in the antidomestic violence. In 2009, the Chinese government tightened the policy about social organizations receiving foreign capital, thus canceling DVN from CLS. Near the introduction of the Anti-domestic Violence Law (2016), DVN announced its dissolution in 2014. In the 1990s, news about domestic violence was rarely released, while many influential presses reported the "Li Yang domestic violence" case became and quickly became hot spots (Southern Weekend, 2011). This news outraged the public from 2011 to 2013. During this period, antidomestic violence NGOs seized this opportunity to popularize the concept of domestic violence by carrying out many projects collectively.

Turning eyes to the authority, as early as 1989 , the first set of formal regulations required that organizational registration be approved by the Ministry of Civil Affairs. Furthermore, in 1992, the Ministry of Justice released Methods for Application for Establishment of Legal Research Organizations, which stated that any prospective legal-research organization must register with the Ministry of Justice. The regulations were modified intermittently, while the core objective is the "dual management system" (shuangchong guanli tizhi). This Chinese unique measure regulates that one organization should not only be managed by its superior department but also monitored by the party committee. In 1995, China undertook an international conference of unprecedented scale in Beijing-The Fourth World Congress of Women, and thereby Chinese government promised to challenge the domestic violence. Two years later, at the Fifteenth Party Congress in 1997, Jiang Zemin put forward that it is necessary to develop intermediary organizations between the state and the civil society to respond to China's reform and opening-up to the outside world. Although NGOs received more recognition compared to the past, they are seldom mentioned in the official documents. Instead, the Chinese government uses terms like "social organizations" or "civil organizations." In 2012, NPC was the first time enacting an anti-domestic violence law in its legislative work plan. From 2012 to 2016, the pace of anti-domestic violence is accelerated. However, in all the reports from the authority, the government merely clearly mentioned its collaboration with one $\mathrm{NGO}-\mathrm{ACWF}$.

\subsection{After 2016: reaffirmation of official authority}

According to the anti-domestic violence law in 2016, the Chinese government states that working against domestic violence is the joint responsibility of the state, society, and family, and "governments at all levels should support social organizations such as social work service agencies in carrying out anti-domestic violence projects" (No.37). In the same year, the Law on Administration of Activities of Overseas Nongovernmental Organizations in the Mainland of China (Overseas NGO Law) was issued, which dictated that foreign NGOs must register with the police to work domestically. In this context, it rationalizes the role of public organizations in terms of anti-domestic violence and emphasizes the authority of the governmental command. After 2016, official reports about antidomestic violence have been remarkably increasing. For example, Beijing Women's Federation will regularly give the government an account of the projects in different districts. One trend is that after 2016, the connections between the Women's Federation and the authority are enhanced in anti-domestic violence, acting as a chosen one by the state. The authority claims that domestic violence is alleviated significantly due to the Law.

Although the development of NGOs remains limited, the efforts of caring for the anti-domestic violence issue have gained official recognition. NGOs are changing themselves isomorphically to build a tighter relationship with the government. After 2016, several NGOs against domestic violence and working on gender equality are reviving. However, one commonality is that these NGOs usually choose their management layers that have a governmental background. Like Beijing Red Maple Women's Psychological Counseling service Center (Beijing Hongfeng) and Beijing Yuanzhong Gender Development Center, their board of directors is CCP members. Compared to the government, NGOs are more efficient in coordinating the individuals and organizations to build a professional team of volunteer lawyers for abused women and children.

These anti-domestic violence NGOs also keep in touch with the Women's Federation, often sharing social resources. Besides, NGOs follow up the process of antidomestic violence after the Law being issued. Beijing Equality, a burgeoning non-governmental organization concerning women's rights established in 2014, releases a comprehensive report about the progress of the antidomestic violence law (2020). In the meantime, the public is paying greater attention to domestic violence, 
and the related stories received more coverage in the media. Southern Weekend, on average, publishes two news reports or interviews yearly, in contrast to a lack of attention in the 2000s.

To summarize, the past two decades witnessed the evolution of the anti-domestic violence movement in China and the localization of the "NGO" concept. This study finds that the competition is among the officials and NGOs in the anti-domestic violence issue. Comparing the timeline from the two sides, both intend to frame the domestic violence issue in China while utilizing different strategies. Furthermore, in 2016, the Chinese first anti-domestic violence law was introduced, remarking as a watershed-the gradual process of imitating each other captured during the changes before and after. In some specific social issues like domestic violence, the states have to rely on NGOs' professional resources to cooperate. Meanwhile, NGOs in China can legitimize themselves by staying in close contact with the government. It is evident that, facing pressure from the authority, NGOs sometimes adopt isomorphic strategies. The government also handles the uncertain stress from the NGOs and the civil society behind them. The following section further discusses the logic of the State-NGO relationship in China according to their actions on the anti-domestic violence issue captured above.

\section{ANALYSIS}

\subsection{Roots of mimetic isomorphism}

The concepts of "NGO" and "anti-domestic violence" were introduced into China almost together. UN Fourth World Conference on Women was held in Beijing embodied China's prospect of associating with the international society. Since Mao's era, gender equality is vaguely included in the national agenda, making it a legitimate topic supported by the government. Furthermore, the market reforms led to the decollectivization and weakened the government's ability to provide public services as much as before. Independent organizations began to participate in politics (Hsu, 2010).

Meanwhile, the government was attempting to localize "NGOs" in the Chinese context. Categories of Chinese NGOs are often based on the various autonomous degrees: government-organized, totally non-governmental, and a semi-governmental hybrid category (Lu, 2007). All-China Women's Federation (ACWF) is a typical government-organized NGO. In 1994, ACWF was defined by the state in terms of its "non-governmental" nature. Under certain circumstances, NGOs can also give legitimacy to the government, and the government believes that the symbolic role of NGOs matters when talking with the international community (Hasmath \& Hsu, 2014).
Although the government encourages domestic violence and the booming of new Chinese NGOs is overwhelming, referring to domestic experience is difficult. When facing an ambiguous problem or symbolic uncertainty, organizations tend to display mimetic behaviors to find a settlement effortlessly (DiMaggio \& Powell, 1983). Examples in Western countries have associated successful anti-domestic violence movements with large scales of women NGOs. The UN adopted the Declaration on the Elimination of All Forms of Violence Against Women (1993), stating that gender violence within both the private and the public sphere is a violation of human rights" (Joachim, 2003, 247). Therefore, One imitative strategy of early Chinese women NGOs was to "frame and legitimize their work as being an issue related to the protection of human rights" like other anti-domestic violence campaigns in the Third World (Ishkanian, 2007, 497). In China, traditional family and gender values are inherent within the familial structure, in which "patrilineality, and gender roles - are closely interweaved and are embedded in the socio-economic and cultural contexts of traditional China" (Hu \& Scott, 2016, 1270). It is unorthodox to make domestic violence, privacy in the traditional view, public policy concerns. Therefore, NGOs' work's focus was to justify anti-domestic violence as a matter of human rights advances instead of a private family matter.

During the early 1990 s to 2000 s, Chinese women NGOs tried to achieve independence as their foreign counterparts did. Facing the vibrant newborn NGOs, the Women' Federation was comparatively passive and relied on cooperation with civil society. Among them, Beijing-based "Network for Combating Domestic Violence in China" (DVN) was pioneering. Due to its substantial influence, DVN played the dominant role that might once have been considered exclusive to ACWF (Keith, Lin \& Lie, 2003). Throughout one decade, DVN devoted itself to promoting itself more non-governmental. Within the organizational governance, DVN's staffing and capital operation were independent and accepted sponsorship from international funds. After 2003, DVN adopted the standard management model of international NGOs"boards of directors and executive layer." Early NGOs sought to frame domestic violence through international shared understandings and improved themselves following the best practices.

\subsection{Coercive pressure in China}

In the 1980s, many social associations emerged, and the government tried to regulate these spontaneous organizations (State Council, Document No. 25, 1984). After the 1990s, the ambiguity of social associations and NGOs in the official announcements is expected in the official documents. The government seldom clarifies 
them clearly, and instead refers to them together. Coercive pressures are exerted on organizations when controls from the government occur (DiMaggio \& Powell, 1983). Chinese NGOs in the late 1990s to 2000s responded to the tightening of political control flexibly. The dual management system is a unique management practice in China, which places obstacles on the operation of many NGOs.

However, in reality, the state cannot implement policy as strict as its regulatory objectives. Many NGOs seized this opportunity. In 2001, the survey (Wang, 2001) showed that the number of NGOs operating without registration under the dual management system was about ten times that of legally registered NGOs. The official registration process was lengthy; some NGOs may have stalled the process while remaining operational. A more common and safe practice was that NGOs placed themselves under the affiliation of one people's organization recognized by the state.

Furthermore, other NGOs' connections and collaboration with ACWF also provided legitimacy. ACWF was like an intermediary zone between civil society and the government. As a result, in the regulatory environment, NGOs are induced to be isomorphic. Chinese quantities of semi-governmental NGOs were shaped to be closer to the former in balancing government and civil society. DVN is still a typical example. From 2000 to 2010, DVN was affiliated with China Law Society (CLS) to guarantee its status during this period. Under the leadership of the State Council, the China Law Society (CAF) is one of 25 people's organizations alongside the China Federation of Literary and Art Circles (CFLAC) and the Chinese Writers Association (CWA). Their chairmen are usually the retired leaders of the Supreme Court and the Supreme Prosecutor's Office. Besides, DVN built a collaborative relationship with ACWF. The antidomestic violence project initiated by DVN also invited the Council of ACWF to play the role of the adviser (Keith, Lin \& Lie, 2016).

Facing the increasing political pressure from the state, however, isomorphism may not be a panacea. When NGOs fail to adapt to the changing policies, they are risky. One turning point was in 2009, and the government issued the document of state foreign exchange administration policies. The sudden tightened policy resulted in many NGOs hardly received foreign sponsorship and encountered difficulties. In 2010, DVN terminated its cooperative relationship with CLS and registered as "Beijing Fanbao."

Similarly, Peking University asked the Women's Legal Aid Center, Peking University Law School to end the affiliation, which does not mean that NGOs can break away from the official regulation, and adversely, they must register formally. In China, if an organization attempts to achieve the authority's embeddedness, it has to face challenges such as the diminishment of autonomy (Reinelt, 1995). To continue carrying on the projects and the missions, NGOs had no choice but to respond to the policies.

The ACWF has been actively addressing the dilemma of finding a true identity to balance its governmental-organized nature and the NGO operation. With the further development of "reform and opening up" in the 1990s, the ACWF sought "characteristics of a civil society organization as opposed to a state organ" (Howell, 1996, 132). ACWF was trying to develop a looser relationship with the Party, and meanwhile, concern for the women's rights topic autonomously. The convening of the Fourth World Congress of Women in 1995 allowed ACWF to encounter overseas women organizations, which made ACWF realize the capacity to act from the bottom-up. Furthermore, accepting the NGO identity can help ACWF expand potential resources and connections, especially from abroad. Rather than simply implementing the government women's policies, ACWF became proactive. For example, ACWF decided to build township business branches to supply financial aids for rural women (White, 1993). Its nationwide influence can be attributed to the political status identified by the government, which provides the convenience of promoting antidomestic violence agenda in China in the long run. At beginning, ACWF was passive, and the collaboration with those NGOs full of anti-domestic violence professional resources is of great significance. After the 2000 s, with the acceleration of introducing restrictive regulations, ACWF gradually expanded, and NGOs rely on ACWF to legitimize themselves (Howell, 1996). ACWF sought to become more independent while other anti-domestic violence NGOs drew closer to the government, ironically, which created an isomorphic situation.

\subsection{Identical demands for the professionalization}

DiMaggio and Powell (1983) argue that the normative pressures will establish a unified cognitive base in one specific field, and professionals in one organization will display the similarities in another. This trend can be captured in the Chinese process of antidomestic violence. One critical drive is personnel screening. Scholars and professionals mainly organized early anti-domestic violence NGOs. Experienced practitioners were scarce, and therefore, the early organized projects depended on the human resources in universities. Primarily, the homogenous educational background contributed to the consensus-building about the anti-domestic violence framework and the possibility of cross-organizational cooperation. For antidomestic violence organizations, there is seldom competition among them. Conversely, extending the 
cooperation with other NGOs can expand the influence through collective action. To convey the appeal of putting the anti-domestic Law on the official agenda in China, the negotiation in advance with different NGOs, including ACWF, avoided deviating from the core resort. Moreover, an allied relationship also helps the quick response to the events in public news. When the "Li Yang domestic violence" case broke out, NGOs' reactions were rapid, and they seized the chance to stress the "domestic violence" to the public.

The movement of professionals across different NGOs also could lead to isomorphic results. In 2016, the anti-domestic violence law was issued, while the Law on the Management of Overseas NGOs was approved, too. The new Law stated that strict supervising of overseas NGOs' activities in China is a necessity, and the government is obligated to ban those organizations with non-conformity. When the Chinese government accelerates legislating anti-domestic violence, it restricts NGOs' development to a higher degree. Where are the professionals when the organizations have dissolved? Taking DVN for example, its decision-making layer was highly elite, and for each individual, they had abundant social and academic resources. Hence, the end of DVN would not finish these professionals' course of working on protecting women's rights. Numbers of them continued to work in ACWF or went back to gender institutes in the universities. They give up their identities in NGOs and instead are incorporated into the official agencies. The accumulated resources of solving domestic violence during the past two decades are not wasted, just transferred (Zhang, 2009).

\section{CONCLUSION}

This paper contributes to the institutional isomorphism theory in two dimensions. First is that the evidence from China expands the explanatory scope of this theory. Coercive isomorphism often occurs when direct or indirect organizational models are imposed on dependent organizations (1983). Since NGOs are independent organizations from the government, previous studies mostly focus on analyze the isomorphic phenomenon among different NGOs in one specific field. China's case offers a possibility that NGOs will imitate each other and result in isostructure. However, the government will also learn from the NGOs' effective modes through ACWF, a unique organization in China. As an officially organized organization, ACWF learns the experience from other NGOs and absorbs expertise. As a result, ACWF and other NGOs display similarities about competency and functions.

Another enhancement is to remind that shift of power may be hidden behind institutional isomorphism. From the late 1990s to the 2000s, ACWF cooperated with active local NGOs and relied on their diverse resources to participate in the anti-domestic violence, which explains the isomorphism during this period. After the 2010s, ACWF gradually takes the initiative in the anti-domestic violence movement when NGOs' development in China stagnates or hinders. Furthermore, it can be captured that NGOs try to get closer to ACWF in a semblable approach, which is secure to gain the government's trust. ACWF has benefited from the relationship between civil NGOs and the government, connecting them as middlemen. Due to ACWF's official-organized nature, it is impossible to be functionally independent of the government, and it is always in the hands of the state. To a great extent, it also paves the way for the government to accept and connect with the civil world as a government agent. The essence behind the isomorphism of NGOs is that the initiative power of Chinese anti-domestic violence has gone through the transformations from NGOs to the state.

By examining how NGOs and the government interacted during anti-domestic violence development in China, one empirical contribution of this paper is to update the understanding of relations between the government and NGOs. Previous studies usually support that NGOs are vital to fostering civil vitality and providing services to supplement government capacity. Hence, whether NGOs are influential is effective greatly based on the Western perspectives-whether NGOs play the democratic role of strengthening civil engagement (Mercer, 2002). The traditional Western perspectives are adapted to conclude examples in the third world. NGOs are supposed to participate in politics and confront the state's monopoly in public affairs. If they failed, NGOs would betray their responsibility of promoting civic participation. However, interactions of NGOs and the government in different developing countries are less predictable than the normative assumption, thus making it necessary to consider how NGOs are embedded into different political contexts. This research on the Chinese anti-domestic violence movement analyzes an interesting contradiction: the public issue is paid more attention, while in the meantime, NGOs are losing space for civic participation. With joint efforts, the anti-domestic violence agenda in China is progressed and finally get legislated. However, NGOs' operating space is becoming confined, and instead, the discourse power of the anti-domestic violence movement is integrated into the government. In the Chinese context, NGOs' development legitimizes the state rather than themselves and enhances the governance capacity. There is no doubt that anti-domestic violence NGOs have played an irreplaceable role in promoting social problems for China. In contrast, the answer may be disappointing for the vision of expanding civil society and strengthening civil autonomy that NGOs were born. 


\section{REFERENCES}

[1] Alchian, A. A. (1950). Uncertainty, evolution, and economic theory. Journal of political economy, 58(3), 211-221.

[2] Anheier, H.K. (2005). Nonprofit Organizations: Theory, Management, Policy. London, Routledge.

[3] Brass, J. N. (2012). Why do NGOs go where they go? Evidence from Kenya. World Development, 40(2), 387-401.

[4] Bratton, M. (1989). The politics of governmentNGO relations in Africa. World Development, 17(4), 569-587.

[5] Batley, R., \& Mcloughlin, C. (2010). Engagement with non-state service providers in fragile states: reconciling state-building and service delivery. Development Policy Review, 28(2), 131-154.

[6] Beijing Women's Federation. (2011). Opinions of Beijing on prevention and suppression of the domestic violence. Rights and Interests Department of Municipal Women's Federation. Available from URL:

http://www.bjwomen.gov.cn/fnw_2nd_web/static/a rticles/catalog_223/article_9182/9182.html.

[7] Beijing Women's Federation. (2013). The All-China Women's Federation proposal: an anti-domestic violence law be included in the NPC's legislative work plan. China Women's News. Available from URL:http://www.bjwomen.gov.cn/fnw_2nd_web/st atic/articles/catalog_14/article_15241/15241.html.

[8] Beijing Women's Federation. (2014). The All-China Women's Federation held a high-level advocacy conference against domestic violence. China Women's News. Available from URL: http://www.bjwomen.gov.cn/fnw_2nd_web/static/a rticles/catalog_14/article_21335/21335.html.

[9] Coninck, J. D. (1992). Evaluating the impact of NGOs in rural poverty alleviation: Uganda country study. Evaluating the impact of NGOs in rural poverty alleviation: Uganda country study.

[10] Clark, Jeffrey. (2000). Civil society, NGOs and development in Ethiopia: a snapshot view. Washington DC: World Bank.

[11] Campbell, J. (2001) Autonomy and governance in Ethiopia: the state, civil society and NGOs. In Barrow O. and Jennings M., editors, The charitable impulse: NGOs and development in east and northeastern Africa. London: James Currey, 282310 .

[12] Clarke, G. (1998). The politics of NGOs in SouthEast Asia: participation and protest in the
Philippines. London: Routledge.

[13] DiMaggio, P. J., \& Powell, W. W. (1983). The iron cage revisited: Institutional isomorphism and collective rationality in organizational fields. American sociological review, 147-160.

[14] Dogra, N. (2013). Representations of global poverty: Aid, development and international NGOs. Bloomsbury Publishing.

[15] Dicklitch, S. 1998: The elusive promise of NGOs in Africa: lessons from Uganda. London: Macmillan.

[16] Dong, Y G. (2015). Double Shelter, Triple Dilemma: The Emergence and end of the Network against Domestic Violence. China Development Brief. Available from URL: http://www.chinadevelopmentbrief.org.cn/news17266.html.

[17] Farrington, J., \& Lewis, D. J. (2014). Nongovernmental organizations and the state in Asia: Rethinking roles in sustainable agricultural development. Routledge.

[18] Fowler, A. (1991). The role of NGOs in changing state-society relations: Perspectives from Eastern and Southern Africa. Development policy review, 9(1), 53-84

[19] Frumkin, P., \& Galaskiewicz, J. (2004). Institutional isomorphism and public sector organizations. Journal of public administration research and theory, 14(3), 283-307.

[20] Fu, X. (1995). The women's pageant is in China: The first time for our country to hold the largest international conference, People's Daily, Available from URL: http://www.people.com.cn/english/9809/22/target/n ewfiles/A104.html.

[21] Gideon, J. (1998). The politics of social service provision through NGOs: A study of Latin America. Bulletin of Latin American Research, 17(3), 303-321.

[22] Hood, C. 1991: A public management for all seasons?. Public administration, 69(1), 3-19.

[23] Hadenius, A., \& Uggla, F. (1996). Making civil society work, promoting democratic development: What can states and donors do?. World development, 24(10), 1621-1639.

[24] Hsu, C. (2010). Beyond civil society: An organizational perspective on state-NGO relations in the People's Republic of China. Journal of Civil Society, 6(3), 259-277. 
[25] Hasmath, R., \& Hsu, J. Y. (2014). Isomorphic pressures, epistemic communities and state-NGO collaboration in China. The China Quarterly, 220, 936-954.

[26] Hu, Y., \& Scott, J. (2016). Family and gender values in China: Generational, geographic, and gender differences. Journal of Family Issues, 37(9), 1267-1293.

[27] Howell, J. (1996). The struggle for survival: Prospects for the Women's Federation in Post-Mao China. World Development, 24(1), 129-143.

[28] Ishkanian, A. 2007: En-gendering Civil Society and Democracy-Building: The Anti-Domestic Violence Campaign in Armenia, Social Politics, 14(4), 488-525.

[29] Joachim, J. (2003). Framing issues and seizing opportunities: The UN, NGOs, and women's rights. International Studies Quarterly, 47(2), 247274.

[30] Keith, R. C., Lin, Z., \& Lie, H. (2003). The making of a Chinese NGO: The research and intervention project on domestic violence. Problems of PostCommunism, 50(6), 38-50.

[31] Mercer, C. (2002). NGOs, civil society and democratization: a critical review of the literature. Progress in development studies, 2(1), 5-22.

[32] Meyer, J. W., \& Rowan, B. (1977). Institutionalized organizations: Formal structure as myth and ceremony. American journal of sociology, 83(2), 340-363.

[33] Morrill, C., \& McKee, C. (1993). Institutional isomorphism and informal social control: Evidence from a community mediation center. Social problems, 40(4), 445-463.

[34] Peters, B. G., \& Pierre, J. (1998). Governance without government? Rethinking public administration. Journal of public administration research and theory, 8(2), 223-243.

[35] Ramanath, R. (2009). Limits to institutional isomorphism: examining internal processes in NGO_-government interactions. Nonprofit and Voluntary Sector Quarterly, 38(1), 51-76.

[36] Reinelt, C. (1995). Moving onto the terrain of the state: The battered women's movement. Feminist organizations: Harvest of the new women's movement, 84-104.

[37] Schild, V. 2002: Engendering the new social citizenship in Chile: NGOs and social provisioning under neo-liberalism. Gender justice, development, and rights, 1(9), 170-204.
[38] State Council Information Office. (2016). Antidomestic Violence Law of the People's Republic of China (Presidential Order No. 37). The state council, Beijing.

[39] State Council. (1989). Regulations on the Registration and Administration of Social Organizations (State Order No. 43). The State Council, Beijing.

[40] The National People's Congress of PRC. (2016). Law on Administration of Activities of Overseas Non-governmental Organizations in the Mainland of China. Standing Committee of the 12th National People's Congress, Beijing.

[41] Woodward, J. (1970). Industrial organization: Behaviour and control. Oxford Univ. Press.

[42] White, G. (1993). Prospects for civil society in China: A case study of Xiaoshan City. The Australian Journal of Chinese Affairs, (29), 63-87.

[43] Wang, M. (2001). The development of NGOs in China. The Nonprofit Review, 1(1), 53-63.

[44] Wu, J. (2015). Li Yang's Case Leads to Calls for Anti-domestic Violence Legislation: "The Chinese thinks it's all about the family”. Southern Weekend. Available from URL: http://www.infzm.com/contents/63072.

[45] Xia, T., \& Feng, Y. (2020). Monitoring Report on the Fourth Anniversary of the Implementation of the Anti-Domestic Violence Law (March 1, 2016 -February 29, 2020). Beijing Equality. Available from

URL:http://www.equalitybeijing.org/newinfo.aspx ?id=80.

[46] Young, C., \& Turner, T. E. (1985). The rise and decline of the Zairian state. University of Wisconsin Pres.

[47] Yiyi, L. (2007). The autonomy of Chinese NGOs: a new perspective. China: An International Journal, 5(02), 173-203.

[48] Zhang, L. (2009, May). Domestic violence network in China: Translating the transnational concept of violence against women into local action. In Women's Studies International Forum (Vol. 32, No. 3, pp. 227-239). Pergamon. 